\title{
ANALISIS PERBANDINGAN PENERAPAN DAN NON \\ PENERAPANTERHADAP TEKNOLOGI SAPTA USAHATANI PADI \\ DI KELURAHAN KEMPAS JAYA KECAMATAN KEMPAS KABUPATEN INDRAGIRI HILIR
}

\author{
Gunawan Syahrantau' ${ }^{1}$, Rano ${ }^{1}$ \\ ${ }^{1}$ Program Studi Agribisnis Fakultas Pertanian UNISI \\ Email: syahrantau_gsr@yahoo.com
}

\begin{abstract}
ABSTRAK
Penelitian ini bertujuanuntuk mengetahui pelaksanaan penerapan dan non penerapanteknologi sapta usahatani padi dan untuk mengetahui perbandingan tingkat efesiensi penerapan dan nonpenerapan teknologi sapta usahatani padi. Metode analisis yang digunakan adalah analisis deskriptif,analisis pendapatancurahan kerja, produktivitas, dananalisis Return Cost Ratio (RCR). Hasil penelitianmenunjukan bahwa usahatani yang dilakukan oleh petani program sapta usahatani lebih baik dibandingkan dengan non program sapta usahatani ditinjau dari aspek pengolahan lahan, pengaturan irigasi, pemilihan benih, pemupukan, pengendalian hama dan penyakit, panen dan pemasaran. Perbandingan petani yang menerapkan sapta usahatani dengan petani non sapta usahatani yaitu pendapatan bersih sapta usahatani Rp. 7.779.907,00 sedangkan non sapta usahatani Rp. 902.048,06.Curahan tenaga kerja 131,29. HOK dan yang non sapta usahatani 72,72 HOK. Produktivitas pada sapta usahatani 5.978,5 kg/Ha sedangkan non sapta usahatani $2.112,61 \mathrm{~kg} / \mathrm{ha}$. Kelayakan finansial dari kedua sistem pertanian padi tersebut dilihat dari nilai Return Cost Ratio (RCR) sudah layak. Usahatani padi yang dilakukan oleh petani yang menerapkan program sapta usahatani memiliki nilai RCR 1,37 dan petani non program sapta usahatani yakni sebesar 1,09 .
\end{abstract}

Kata Kunci : padi sawah, teknologi sapta usahatani, produktivitas, efisiensi

\section{PENDAHULUAN}

Padi (Oryza sativa L.) merupakan bahan makanan pokok sebagian besar rakyat Indonesia, karena sekitar $95 \%$ penduduk Indonesia mengkonsumsi beras. Tingginya kebutuhan konsumsi beras, disebabkan oleh sebagian besar penduduk Indonesia beranggapan bahwa beras merupakan bahan makanan pokok yang belum dapat digantiakan keberadaanya. Disisi lain luas tanaman padi menurun $0,5 \%$ dan menurunya areal-areal karena dialihfungsikan menjadi pemukiman penduduk, sarana transportasi, dan lain-lain. Disamping itu keterbatasan sarana produksi atau alat pertanian dan kurangnya sumberdaya manusia 
berkualitas dapat melaksanakan usahatani secara efektif dan efisien (Sumudoningrat, 2001)

Pada masa mendatang, tantangan terhadap ketahanan pangan (Beras) semakin berat karena adanya peningkatan jumlah penduduk dari tahun ketahun yang besarnya diperkirakan 1,49\%/tahun dan semakin sempitnya lahan pertanian yang disebabkan adanya alih fungsi lahan kesektor lain. Salah satu cara untuk mencegah permasalahan tersebut adalah denga melaksanakan program intensifikasi yaitu dengan menerafkan teknologi pertanian melaui kegiatan : (1) penggunaan benih unggul, (2) pengairan yang teratur, (3) cara bercocok tanam sesuai dengan anjuran, (4) melakukan pemupukan sesuai dengan rekomendasi, (5) pengendalian hama dan penyakit, (6) melakukan panen dan fasca panen dengan baik serta (7) pemasaran hasil.

Kabupaten Indragiri Hilir merupakan salah satu daerah yang memiliki sektor pertanian yang yang membantu prekonomian daerah. Dengan jumlah penduduk yang bermata pencarian disektor ini sekitar $74,39 \%$, hal ini menunjukan bahwa sektor pertanian harus mendapat perhatian khusus oleh pemerintah seperti, mendorong petani untuk menerapkan teknologi sapta usahatani guna tercapainya kesejahteraan bagi petani. Kecamatan kempas merupakan daerah yang memiliki produksi padi yang tinggi setiap tahunnya (DTPHP, 2016).

Salah satu daerah penghasil komoditi padi di Kecamatan Kempas adalah Kelurahan Kempas Jaya yang telah giat melaksanakan intensifikasi padi sawah dengan penerapan teknologi sapta usahatani, salah satunya adalah Kelompok Tani Makmur dengan jumlah produksi 6,5 ton/Ha, namun sebagian kecil di daerah tersebut masih ada kelompok tani yang belum menerapkan teknologi sapta usahatani sepenuhnya.

Diantara 12 kelompok tani ada salah satu kelompot tani yang belum menerapkan teknologi sapta usahatani yaitu kelompot tani Serba Mau dengan jumlah produksi 2,5 ton/Ha sehingga timbul suatu perbandingan produksi yang jauh berbeda antara petani yang menerapkan teknologi sapta usahatani dengan petani yang belum menerapkan sapta usahatani. Tujuan penelitian ini adalah untuk mengetahui pelaksanaan dan tingkat efesiensi penerapan dan tanpa penerapan teknologi sapta usaha tani padi di di Kelurahan Kempas Jaya Kecamatan Kempas.

\section{TINJAUAN PUSTAKA}

\subsection{Tanaman Padi (OrizSativa)}

Padi (Oryza sativa L.)merupakan tanaman penting di Indonesia karena merupakan sumber bahan makanan pokok sebagian besar masyarakat. Dalam bahasa latin, padi disebut dengan Oriza sativa L., masuk dalam famili Poacae (Gramincae), tanaman semak semusim ini mrupakan taman yang berbatang basah, dengan tinggi antara $50 \mathrm{~cm}-1,5 \mathrm{~m}$. batangnya tegak lunak, beruas berongga, kasar dan berwarna hijau. Padi mempunyai daun tunggal berbentuk pita yang panjangnya 15$30 \mathrm{~cm}$. ujungnya runcing tepinya rata, berpelepah, bertulang sejajar, dan berwarna hijau. Bunganya majemuk berbentuk malai. Buahnya seperti buah batu (keras) dan terjurai pada 
tangkai. Setelah tua, warna hijau akan menjadi kuning. Bijinya keras, berbentuk bulat telur, ada yang berwarna putih atau merah. Butirbutir padi yang lepas dari tangkainya disebut gabah, dan yang sudah dibuang kulit luarnya disebut beras. Bila beras ini dimasak, maka namanya menjadi nasi, yang merupaka bahan makanan utama bagi sebagian besar penduduk Indonesia (Deptan, 2008).

Padi tumbuh diberbagai lingkungan produksi diantaranya sawah irigasi, lahan kering tadah hujan, pasang surut dan lebak atau rawa. Dari berbagai tipologi ini, lahan sawah irigasi (teknis, setengah teknis, sederhana, desa) mendominasi area produksi padi di Indonesia (Novizar, 2000).

\subsection{Peningkatan Produktivitas}

Teknologi dalam usaha pertanian selalu berubah disesuaikan dengan situasi dan kondisi. Misalnya varietas tanaman selalu berganti disesuaikan pada daya tahan terhadap serangan hama dan penyakit, selera atau rasa. Pada situasi seperti ini tenaga kerja pertanian yang berlebihan maka teknologi yang dianjurkan lebih baik pada teknologi padat tenaga kerja. Dalam kaitanya dengan sekala ekonomi, maka perlu adanya segmentasi kerja yaitu kegiatan yang memerlukan teknologi padat modal dapat dikerjakan oleh perusahaan besar seperti kegiatan transfer teknologi. Pengadaan saprodi, pengolahan dan pemasaran. Sebaiknya kegiatan yang menggunakan teknologi yang tidak padat modal dapat diserahkan pada perusahaan kecil atau petani (Soekartawi, 1994).

$$
\text { Peningkatan produktivitas }
$$$$
\text { usahatani tanaman padi sangat }
$$

dibutuhkan dalam rangka pemenuhan kebutuhan pangan rakyat Indonesia. Dimana padi merupakan bahan makanan pokok masyarakat Indonesia. untuk itu Badan Pengkajian Teknologi Pertanian (BPTP) menciptakan komponen teknologi PPT yaitu pengelolaan tanaman terpadu yang terdiri dari varietas unggul, persemaian, bibit, sitem tanam, pemupukan berimbang, penggunaan bahan organik, pengendalian hama dan penyakit panen dan pasca panen. Kesinergian komponen PPT mampu meningkatkan produktivitas padi. (Sembiring, 2001).

Budidaya padi pada prinsipnya memadukan berbagai komponen teknologi saling menunjang (sinergis) guna meningkatkan efektivitas dan efisiensi usahatani seperti selama ini telah dikembangkan dilahan irigasi. Dilahan rawa pasang surut, kemajuan teknologi seperti perakitan varietas baru, pengelolaan tatamikro, pengelolaan hara tanaman sesuai tipologi lahan, peningkatan monitoring hama dan penyakait, ameliorasi lahan yang disertai dengan penerapan beberapa komponen teknologi lain yang saling menunjang diharapakan dapat juga berhasil seperti halnya pendekatan pengembangan PTT dilahan irigasi. Akan tetapi dilahan pasang surut suatu perhatian khusus diperlukan penerapan teknologi spesifik lokasi dan tidak bisa disama ratakan.

Komponen teknologi yang dapat di introduksikan dalam pengembangan usahatani padi di lahan pasang surut terdiri dari:

1. Varietas unggul yang sesuai dengan karakteristik lahan, lingkungan, bentuk gabah 
maupun rasa nasi yang diinginkan oleh petani setempat.

2. Benih bermutu (kemurnian dan daya kecambah yang tinggi).

3. Jumlah bibit 2-3 batang per lubang dan tanam dengan sistem jajar legowo 2:1, 4:1, dan lainya dengan populasi minimum 250.000 rumpun/Ha atau tanam dengan sistem tabela.

4. Pengelolaan tata air mikro dengan sistem tata air satu arah dengan saluran keliling dan kemalir, pintu-pintu air (flapgate) masuk dan keluar serta stoplong, saluran kemalir dibuat dengan inteval 6-8 $\mathrm{m}$ yang disertai dengan caren-caren.

5. Pemberian pupuk urea harus sesuai dengan dosis yang telah ditentukan

6. Pemberian pupuk $\mathrm{P}$ dan $\mathrm{K}$ didasarkan sesuai dengan status hara tanah.

7. Pengendalian gulma secara terpadu.

8. Pengendalian hama dan penyakit secara terpadu (PHT)

9. Panen dan pasca panen menggunakan alat perontok.

Penerapan suatu teknologi baru dalam pertanian sering mengalami hambatan. Hasil-hasil penelitian menunjukan bahwa teknologi dalam pertanian tidak selalu diadopsi oleh para petani. Sebagian petani memutuskan untuk mengadopsi teknologi baru tersebut sedang sebagian memutuskan untuk tidak mengadopsinya (Birowo, 1974).

\subsection{Sapta Usahatani}

Revolusi hijau Merupakan usaha pengembangan teknologi pertanian untuk meningkatkan produksi pangan. Mengubah dari pertanian tradisional menjadi pertanian yang menggunakan teknologi lebih maju. Diawali oleh Ford dan Rockefeller Foundation, yang mengembangkan gandum di Meksiko (1950) dan padi di Filipina (1960). Revolusi hijau menekankan pada Serealia: padi, jagung, gandum, dan lain-lainya. Revolusi hijau di Indonesia dilakukan dengan ekstensifikasi dan intensifikasi pertanian. Ekstensifikasi dengan perluasan areal. Terbatasnya areal, menyebabkan pengembangan lebih banyak pada intensifikasi. Intensifikasi dilakukan denga sapta usahatani yaitu :

1. Penggunaan Benih yang Unggul

Benih unggul adalah jenis benih yang memiliki sifat-sifat menguntungkan bagi peningkatan produksi pangan. Pemilihan benih sangat berpengaruh besar pada hasil panen yang akan dihasilkan nantinya. Berikut ini adalah beberapa jenis benih unggul yang digunakan oleh petani di Kelurahan Kempas Jaya yaitu benih IR 42 dan Inpara.

Pemilihan benih unggul juga sangat menunjang akan hasil padi yang dihasilkan nantinya. Adapun ciri-ciri benih yang baik adalah sebagai berikut : Berlabel, Bermutu Tinggi, VUTW (Varietas Unggul Tahan Wereng), Kemampuan Berproduksi Tinggi.

\section{Pengolahan Lahan}

Proses kedua yang dilakukan pada sapta usaha tani adalah pengolahan tanah secara baik. Mengolah tanah bertujuan agar tanah yang ditanami dapat menumbuhkan tanaman secara baik dan membuahkan hasil yang berlimpah. Berikut ini adalah syarat-syarat tanah yang baik adalah:

a. Memiliki cukup rongga udara, gembur, dan tidak padat. 
b. Mengandung banyak unsur organik.

c. Banyak mengandung mineral dan unsur hara.

d. Mampu menahan air.

e. Memiliki kadar asam dan basa tertentu.

\section{Pengaturan Irigasi}

Untuk meningkatkan produksi perlu diatur sistem irigasi atau pengairan yang baik karena air merupakan Air bagi lahan petanian juga berfungsi membantu mengurangi atau menambah kesamaan tanah. Air membantu pelarutan garam-garam mineral yang sangat diperlukam oleh tumbuhan.

\section{Pemupukan}

Memberikan pupuk pada tanaman pada prinsipnya adalah memberikan zat-zat makanan yang diperlukan bagi pertumbuhan tanaman. Pemupukan harus dilakukan dengan tepat, baik dalam jumlah pupuk, masa pemupukan maupun jenis pupuknya. Pupuk dapat digolongkan menjadi beberapa jenis menurut proses terjadinya/cara pembuatanya, menurut asalnya, dan menurut unsur hara yang terdapat/terkandung di dalamnya. Berdasarkan proses terjadinya/proses pembuatannya pupuk dapat dibedakan menjadi dua macam yaitupupuk alami dan pupuk buatan.

\section{Pemberantasan Hama dan Penyakit \\ Proses selanjutnya adalah pemberantasan hama,gulma,dan penyakit. Serangan hama dan penyakit tanaman akan menurunkan tingkat produktifitas tanaman bahkan gagal sama sekali.}
6. Penanganan Panen dan Pasca Panen

Pasca panen adalah kegiatan yang dilakukan para petani setelah melakukan panen. Di pulau jawa panen dilakukan tiga kali dalam satu tahun, dengan umur padi sampai dengan panen kurang lebih empat bulan. Contoh kegiatannya antara lain menanam jenis tanaman yang berbeda (selain tanaman pokok) yang umurnya pendek. Hal ini ditujukan untuk mengembalikan kesuburan tanah. Selain itu juga dapat menambah penghasilan petani

\section{Pemasaran}

$$
\text { Pemasaran yang baik }
$$
termasuk hal yang penting dalam sapta usaha tani. Misalnya, apabila hasil panen baik tetapi cara pemasaran kurang sama saja petani akan merugi. Petani dapat menjual beras kepada BULOG ataupum kepada pedagang beras di pasar beras.

\section{METODE PENELITIAN}

\subsection{Tempat dan Waktu Penelitian}

Penelitian ini dilaksanakan di Kelurahan Kempas Jaya, Kecamatan Kempas Kabupaten Indragiri Hilir. Alasan dipilihnya tempat ini sebagai tempat penelitian karena merupakan sentral gabah dan tempat dimana petani telah banyak menerapkan teknologi. Penelitian dilakukan selama 3 bulan yaitu September sampai November 2016.

\subsection{Jenis dan Sumber Data}

Data yang digunakan dalam penelitian ini adalah data primer dan data skunder. Data primer diperoleh dengan pengamatan dan wawancara langsung kepada petani dengan alat bantu kuesioner.Data sekunder 
diperoleh dari instansi-instansi yang terkait diantaranya, Dinas Tanaman Pangan, Hortikultura dan Peternakan (DTPHP) dan Kantor Kelurahan Kempas Jaya.

\subsection{Populasi dan Sampel}

Metode yang digunakan dalam penentuan sampel berdasarkan populasi petani kemudian dibagi menjadi dua kelompok, yaitu petani yang menerapkan dan yang tidak menerapkan teknologi sapta usahatani. Kelompok tani yang menerapkan teknologi sapta usahatani adalah kelompok tani MAKMUR dengan jumlah anggota 30 orang sedangkan kelompok tani yang tidak menerapkan adalah kelompok tani SERBA MAU dengan jumlah anggota 30 orang. Dalam penelitian ini teknik pengambilan sampel menggunakan metode Random Sampling, dimana semua anggota populasi yang dijadikan sampel hanya diambil 50\% yaitu kelompok tani makmur 15 orang dan kelompok tani seba mau 15 orang dikarena populasi sampel bersipat homogen.

\subsection{Metode Analisis Data}

\begin{tabular}{ll}
\multicolumn{1}{c}{ Data dianalisis } & dengan \\
menggunakan & analisis \\
deskriptif.Untuk & melihat
\end{tabular}
perbandingan antara petani yang menerapkan teknologi sapta usahatani padi dan petani yang tidak menerapkan teknologi sapta usaha tani dilihat berdasarkanbiaya produksi, pendapatan bersih, curahan tenaga kerja, produktivitas lahan dan produktivitas tenaga kerja.

Sedangkan untuk menghitung nilai efisiensi digunakan kriteria investasi $\mathrm{R} / \mathrm{C}$ ratio. Pada penelitian digunakan dua perhitungan $\mathrm{R} / \mathrm{C}$ yaitu perhitungan analisis usahatani yang benar-benar dikeluarkan oleh petani dan $\mathrm{R} / \mathrm{C}$ perhitungan analisis usahatani melalui pendekan biaya oportunitas. berikut formula yang digunakan.

$$
\mathrm{R} / \mathrm{C} \text { ratio }=\frac{\text { Total Penerimaan }}{\text { Total Biaya Produksi }}
$$

Dimana kriteria :

1. $\mathrm{R} / \mathrm{C}>1$ layak

2. $\mathrm{R} / \mathrm{C}<1$ tidak layak

3. $\mathrm{R} / \mathrm{C}=1$ layak even Point

\section{HASIL DAN PEMBAHASAN}

\subsection{Pengelolaan Usahatani Padi}

Sapta Usaha Tani merupakan sebuah program pemberdayaan petani dengan cara intensifikasi pertanian. Sapta Usaha Tani merupakan pengembangan dari program Panca Usaha Tani. Adapun Pengelolaan usaha tani padi yang dilakukan di Kelurahan Kempas Jayaoleh petani yang mengikuti program Sapta Usaha Tani dan Non Sapta Usaha Tani akan dijelaskan pada poin berikut:

\subsubsection{Pengolahan Tanah}

Pengolahan lahan merupakan proses penyiapan lahan untuk usaha tani padi. Pengolahan lahan bertujuan mengubah keadaan tanah pertanian dengan alat tertentu hingga memperoleh susunan tanah (struktur tanah) yang dikehendaki oleh tanaman. Adapun perbedaan pengelolaan tanah antara petani yang mengikuti program sapta usaha tani dan non sapta usaha tani adalah :

1. Petani yang mengikuti program sapta usaha tani melakukan pengelolaan tanah dengan sistem mekanisasi tanpa penyemprotan herbisida dan alat tradisional seperti cangkul. 
2. Petani yang tidak mengikuti program sapta usaha tani melakukan pengelolaan lahan mulai dari penyemprotan lahan dengan herbisida. Herbisida diaplikasikan dengan dosis 10 liter per hektar dengan harga herbisisda Rp.65.000 per liter.

3. Petani yang mengikuti program non sapta usaha tani melakukan pengelolaan tanah dengan penyemprotan herbisida dan alat tradisional seperti cangkul.

\subsubsection{Pengaturan Irigasi}

Pengolahan irigasi bertujuan untuk mengubah sifat fisik tanah agar lapisan yang semula keras menjadi datar dan melumpur. Dengan begitu gulma akan mati dan membusuk menjadi humus, aerasi tanah menjadi lebih baik, lapisan bawah tanah menjadi jenuh air sehingga dapat menghemat air. Adapun perbedaan pengelolaan irigasi antara petani yang mengikuti program sapta usaha tani dan non sapta usaha tani adalah :

1. Petani yang mengikuti program sapta usaha tani melakukan pengairan sawah yang terkontrol sesuai dengan kebutuhan seperti halnya lahan sawah petani non sapta usaha tani. Akan tetapi yang membedakan keduanya adalah daya serap tanah. Lahan sapta usaha tani akan cenderung lebih cepat jenuh dan mengurangi daya infiltrasi tanah sehingga penggunaan air akan lebih hemat dan mudah dikontrol. Hal tersebut akan berlaku sebaliknya untuk lahan non sapta usahatani.

\subsubsection{Pemilihan Benih}

Cara pemilihan bibit merupakan cara yang ditempuh oleh petani untuk memilih bibit padi yang unggul untuk dikembangkan. Adapun perbedaan pemilihan antara petani yang mengikuti program sapta usaha tani dan non sapta usaha tani adalah :

1. Petani yang mengikuti program Sapta Usaha Tani telah menggunakan benih unggul nasional dengan tingkat produktivitas mencapai 5.978,5 $\mathrm{kg}$ per hektar. Kebutuhan benih padi unggul sebanyak $30 \mathrm{Kg}$ per hektar dengan harga benih sebesar Rp. 8.000 per kilogram.

2. Petani yang tidak mengikuti program sapta usaha tani menggunakan benih lokal dengan tingkat produktivitas mencapai 2.122,61 per hektar. Kebutuhan benih padi unggul sebanyak $40 \mathrm{Kg}$ per hektar dengan harga benih sebesar Rp. 6.000 per kilogram.

\subsubsection{Pemupukan}

Tujuan pemupukan adalah untuk mencukupi kebutuhan makanan (hara). Pemupukan dilakukan secara berimbang dengan mempertimbangkan $4 \mathrm{~T}$ yakni: tepat dosis, tepat waktu, tepat guna dan tepat tempat. Adapun perbedaan sistem pemupukan antara petani yang mengikuti program sapta usaha tani dan non sapta usaha tani sangat signifikan, untuk lebih jelas dapat dilihat pada poin berikut:

1. Petani yang mengikuti program sapta usaha tani melakukan pemupukan sesuai dengan $4 \mathrm{~T}$ (tepat dosis, tepat waktu, tepat guna dan tepat tempat). Dengan kebutuhan pupuk Urea sebanyak $70 \mathrm{Kg}$ per hektar, SP36 sebanyak $70 \mathrm{~kg}$ per hektar dan KCL sebanyak $65 \mathrm{Kg}$ per hektar.

2. Petani non sapta usaha tani tidak melakukan pemupukan seperti 
yang dilakukan oleh petani yang mengikuti program sapta usaha tani. Hal tersebut akan mengakibatkan penurunan produktivitas lahan secara perlahan karena pengurangan residu unsur hara tanah.

\subsubsection{Pengendalian Hama dan Penyakit}

Hama dan penyakit tanaman merupakan jasad pengganggu. Hendaknya serangan jasad pengganggu ini dikendalikan dengan sedemikian rupa, sehingga tidak menimbulkan kerugian yang berarti. Pengendalian yang bijak dan mempertimbangkan lingkungan harus dilakukan dengan metoda $4 \mathrm{~T}$ yakni tepat dosis, tepat waktu, tepat guna dan tepat tempat. Adapun perbedaan pengendalian antara petani yang mengikuti program sapta usaha tani dan non sapta usaha tani masih bersifat parsial, untuk lebih jelas dapat dilihat pada poin poin berikut.

1. Petani yang mengikuti program sapta usaha tani telah melakukan pengendalian hama dan penyakit tanaman sesuai dengan ketentuan $4 \mathrm{~T}$ (tepat dosis, tepat waktu, tepat guna dan tepat tempat).

2. Petani yang tidak mengikuti program sapta usaha tani masih belum melakukan pengendalian hama dan penyakit tanaman sesuai dengan ketentuan $4 \mathrm{~T}$ (tepat dosis, tepat waktu, tepat guna dan tepat tempat).

\subsubsection{Pasca Panen}

Cara pengolahan hasil panen yang dilakukan petani padi di daerah penelitian meliputi beberapa tahap, yaitu pembersihan, pengeringan, penyimpanan dan penggilingan menjadi beras. Hasil penelitian menunjukkan bahwa seluruh petani melakukan tahap - tahap pengolahan hasil panen tersebut. Adapun perbedaan sistem pengolahan pasca panen antara petani yang mengikuti program sapta usaha tani dan non sapta usaha tani sangat signifikan, untuk lebih jelas dapat dilihat pada poin berikut:

1. Pengelolaan pasca panen untuk petani yang mengikuti program sapta usaha tani telah terkontrol dengan baik. Hal tersebut terlihat dari kemajuan mindset petani tentang margin keuntungan substem hilir. Dimana sekitar 70 persen dari total panen diolah menjadi beras sebelum dilakukannya pemasaran.

2. Petani non program sapta usaha tani tidak melakukan pengelolaan pasca panen gabah sebelum pemasaran. Gabah hasil produksi langsung dijual kepada tengkulak dengan harga Rp.4.500,00/kg.

\subsubsection{Pemasaran}

Pada permasaran hasil pertanian ini tidak memiliki perbedaan yang signifikan antara petani yang menerapkan teknologi sapta usahatani dan petani non sapta usahatani. Pada kelompok tani yang menerapkan teknologi sapta usahatani, mereka tidak menjual hasil panennya dalam bentuk gabah melainkan setelah hasil panen terkumpul mereka mengolah gabah tersebut menjadi beras kemudian dijual kepada pedagang pengumpul yang ada di Kelurahan Kempas Jaya dengan Harga jual Rp.9000/kg, kemudian pedagang pengumpul tersebut menjual kepada pedagang pengecer yang tersebar di Indragiri Hilir dan di Indragiri Hulu, dan begitu juga denga kelompoktani 
yang tidak menerapkan teknologi sapta usahatani.

\subsection{Analisis Usahatani Padi}

\subsubsection{Biaya Produksi}

Biaya produksi adalah total biaya yang dikeluarkan oleh petani dalam selama melakukan proses usaha tani. Total biaya produksi terbagi atas 2 jenis biaya diantaranya adalah biaya variabel dan biaya tetap. Biaya produksi berbanding lurus dengan luas lahan produksi pertanian yang diusahakan. Semakin luas lahan pertanian yang diusahakan Biaya produksi yang dikelurakan oleh petani akan semakin besar dan sebaliknya. Biaya usaha tani padi di Kelurahan Kempas Jaya dapat dilihat pada Tabel 1.

Tabel 1. Rekapitulasi biaya yang digunakan dalam usahatani padi di Kelurahan Kempas Jaya/ha

\begin{tabular}{|c|c|c|c|}
\hline No & Uraian & \multicolumn{2}{|c|}{ Jumlah (Rp) } \\
\hline 1 & Biaya Tetap & $\begin{array}{l}\text { Sapta Usahatani } \\
\text { (Rp) }\end{array}$ & $\begin{array}{c}\text { Non Sapta } \\
\text { Usahatani }(\mathbf{R p})\end{array}$ \\
\hline & a) Benih & $240.000,00$ & $239.080,46$ \\
\hline & b) Pupuk Urea & $222.043,02$ & \\
\hline & c) Pupuk SP36 & $222.043,02$ & \\
\hline & d) Pupuk KCL & $227.822,58$ & \\
\hline & e) Kaptur & $163.978,50$ & $164.750,95$ \\
\hline & f) Klensek & $217.741,94$ & $137.931,03$ \\
\hline & g) Danke & $145.161,29$ & $82.375,48$ \\
\hline & $\begin{array}{l}\text { h) Herbisida Pembuka } \\
\text { lahan }\end{array}$ & - & $647.509,57$ \\
\hline & i) Traktor Pengolahan & $994.623,66$ & - \\
\hline & j) $\quad$ Penanaman & $1.193 .548,39$ & $1.394 .636,01$ \\
\hline & k) Penyiangan & $397.849,47$ & $39.8467,44$ \\
\hline & 1) Panen & $3.978 .494,63$ & $1.195 .402,29$ \\
\hline 2 & Biaya Tidak Tetap & & \\
\hline & a. Sewa Lahan & 8.824 .258 .07 & $2.865 .517,24$ \\
\hline & $\begin{array}{ll}\text { b. } & \text { Tenaga kerja } \\
\text { - dalam keluarga } \\
\text { - Luar keluarga }\end{array}$ & $\begin{array}{r}547.000,00 \\
3.503 .000,00 \\
\end{array}$ & $\begin{array}{l}1.353 .500,00 \\
1.363 .000,00\end{array}$ \\
\hline & c. Cangkul & 18.206 .52 & $11.016,97$ \\
\hline & d. Parang & 36989,24 & $22.681,98$ \\
\hline & e. Arit & $14.623,66$ & $10.421,46$ \\
\hline & f. $\quad$ Sprayer & $50.698,06$ & $36.947,83$ \\
\hline 3 & Total Biaya & $20.998 .082,05$ & $9.923 .238,71$ \\
\hline
\end{tabular}

Sumber : Data primer diolah 2016

Berdasarkan Tabel 1 dapat di ambil beberapa pernyataan yang menggambarkan perbedaan pengelolaan usaha tani padi yang dilakukan oleh petani yang mengikuti program sapta usahatani dan non sapta usaha tani di
Kelurahan Kempas Jaya. Petani yang mengikuti program sapta usaha tani membutuhkan biaya yang lebih besar dari pada non sapta usaha tani sebesar 38,07 persen dari total biaya yang dikeluarkan petani non sapta usaha tani. Selisih total biaya 
tersebut untuk lebih jelas dapat dilihat pada pembahasan berikut.

1. Biaya variabel benih pada dasarnya tidak berbeda secara nominal. Kebutuhan biaya variabel benih untuk 1 hektar lahan padi adalah Rp.238.709,68. Hal tersebut dilihat dari kebutuhan benih dan harga benih (benih lokal Rp.6.000,00/kg dengan kebutuhan 40,00 kg benih per hektar dan benih unggul Rp.8000,00/kg dengan kebutuhan $30,00 \mathrm{~kg}$ benih per hektar). Nominal yang tertera pada tabel berbeda disebabkan karena perbedaan rata - rata luas lahan petani sampel.

2. Biaya variabel pupuk antara petani program sapta usaha tani dan non sapta usaha tani berbeda secara signifikan. Hal tersebut disebabkan karena petani non program sapta usaha tani tidak melakukan pemupukan dalam usaha tani padinya.

3. Biaya variabel pestisida antara petani program sapta usaha tani dan non sapta usaha tani berbeda secara parsial. Hal tersebut disebabkan karena perbedaan pada dosis dan harga pestisida itu sendiri. Dosis penggunaan pestisida petani non program sapta usaha tani lebih rendah daripada petani program sapta usaha tani dan aplikasinya belum sepenuhnya mengikuti aturan sistem $4 \mathrm{~T}$ (tepat dosis, tepat waktu, tepat tempat, tepat guna).

4. Biaya variabel herbisida antara petani program sapta usaha tani dan non sapta usaha tani berbeda secara signifikan. Hal tersebut disebabkan karena hanya petani non sapta usaha tani yang mengaplikasikan herbisida pada awal pengelolaan lahan.
Sedangkan untuk petani program sapta usaha tani menggunakan traktor pada pengelolaan lahan.

5. Biaya variabel penggunaan traktor untuk pengelolaan usaha tani bersifat parsial dikarenakan karena perbedaan volume penggunaannya saja. Hal tersebut menyebabkan terjadinya penggunaan tenaga kerja dalam keluarga untuk usaha tani non program sapta usaha tani.

6. Biaya sewa lahan merupakan biaya yang dipengaruhi oleh pendapatan dari usaha tani. Biaya sewa lahan bernilai 30 persen dari total pendapatan usaha tani. Hal tersebut menyebabkan biaya sewa berbanding lurus dengan total pendapatan usaha tani. Semakin besar pendapatan usaha tani maka biaya sewa semakin besar dan sebaliknya.

7. Biaya tenaga kerja pada program sapta usaha tani sebesar 547.000 (TKDK) dan 3.503.000 (TKLK), sedangkan biaya tenaga kerja padanon sapta usaha tani sebesar
1.353 .500
(TKDK)
dan
1.363.000 (TKLK).

8. Biaya tetap lainnya seperti cangkul, parang, arit dan knapsak ralatif sama. Hal tersebut tergantung dari jumlah dan harga beli.

\subsubsection{Pendapatan}

Pendapatan usahatani menurut Gustiyana (2004), dapat dibagi menjadi dua pengertian, yaitu pendapatan kotor dan pendapatan bersih.Dalam pendapatan usahatani ada dua unsur yang digunakan yaitu unsur penerimaan dan pengeluaran dari usahatani tersebut. Penerimaan adalah hasil perkalian jumlah produk total dengan satuan harga jual, sedangkan pengeluaran atau biaya 
yang dimaksudkan sebagai nilai penggunaan sarana produksi dan lain-lain yang dikeluarkan pada proses produksi tersebut. Produksi berkaitan dengan penerimaan dan biaya produksi, penerimaan tersebut diterima petani karena masih harus dikurangi dengan biaya produksi yaitu keseluruhan biaya yang dipakai dalam proses produksi tersebut (Mubyarto, 1989).

Untuk melihat pendapatan petani padi di Kelurahan Kempas Jaya yang terdiri dari petani program sapta usaha tani dan petani non sapta usaha tani dapat dilihat pada Tabel 2.

Tabel 2. Rekapitulasi pendapatandalam usaha tani padi di Kelurahan Kempas Jaya/ha

\begin{tabular}{|r|l|r|r|}
\hline No & \multicolumn{1}{|c|}{ Keterangan } & Sapta Usaha Tani & Non Sapta Usaha \\
\hline 1 & Produksi gabah $(\mathrm{kg})$ & $5.978,80$ & $2.122,61$ \\
\hline 2 & Diolah menjadi beras $(\mathrm{kg})$ & 3587,28 & 1273,57 \\
\hline 4 & Harga jual beras $(\mathrm{Rp})$ & $9.000,00$ & $9.000,00$ \\
\hline 5 & Total pendapatan kotor & $28.777 .989,25$ & $10.825 .287,36$ \\
\hline 6 & Biaya pengolahan gabah & $1.706 .849,46$ & $636.781,61$ \\
\hline 7 & Total biaya produksi $(\mathrm{Rp})$ & $20.998 .082,05$ & $9.923 .238,71$ \\
\hline 8 & Total pendapatan bersih & $7.779 .907,00$ & $902.048,06$ \\
\hline
\end{tabular}

Sumber: Data Primer Diolah, 2016

Dari Tabel 2 dapat disimpulkan bahwa pendapatan petani program sapta usaha tani lebih tinggi yakni sebesar Rp. 7.779.907,00 dalam satu kali proses produksi. Sedangkan petani non program sapta usaha tani hanya sebesar Rp.902.048,06 dalam sekali proses produksi.

Pendapatan antara petani program sapta usaha tani dan non program sapta usahatani sangat dipengaruhi oleh produktivitas lahan. Semakin tinggi produktivitas lahan maka pendapatan semakin tinggi. Hal tersebut mengindikasikan bahwa apabila petani non program sapta usaha tani ingin mendapatakan pendapatan yang sama maka harus melakukan ekstensifikasi lahan sebesar 2,62 kali dari luas lahannya.

\subsubsection{Curahan Tenaga Kerja dan Produktivitas Tenaga kerja}

Usaha tani padi yang dilakukan oleh petani program sapta usaha tani telah banyak menggunakan mekanisasi sehingga curahan tenaga kerja petani lebih sedikit daripada usaha tani yang dilakukan oleh petani non program sapta usaha tani yang masih menggunakan mekanisasi disebagian kegiatan usaha taninya saja.

Produktivitas merupakan perbandingan antara hasil yang dicapai (keluaran) dengan keseluruhan sumber daya (masukan) yang dipergunakan per satuan waktu. Peningkatan produktivitas faktor manusia merupakan sasaran strategis karena peningkatan produktivitas faktor-faktor lain sangat tergantung pada kemajuan tenaga manusia yang memanfaatkannya. Kualitas dan kemampuan dipengaruhi: Tingkat pendidikan, Latihan / pengalaman, Motivasi, Etos kerja, mental dan fisik. Sedangkan sarana pendukung produktivitas yakni lingkungan kerja 
dan kesejahteraan. Untuk melihat produktivitas tenaga kerja petani padi di Kelurahan Kempas Jaya yang terdiri dari petani program sapta usaha tani dan petani non sapta usaha tani dapat dilihat pada Tabel 4.

Tabel 4. Rekapitulasi produktivitas tenaga kerja dalam usaha tani padi di Kelurahan Kempas Jaya

\begin{tabular}{|r|l|r|r|}
\hline No & Keterangan & Sapta Usaha Tani (Rp) & Non Sapta Usaha Tani \\
\hline 1 & Total Produksi & $5.978,5$ & $2.122,61$ \\
\hline 2 & HOK & 131,29 & 72,72 \\
\hline 3 & Produktivitas & 45.54 & 29,19 \\
\hline
\end{tabular}

Sumber: Data Primer Diolah, 2016

Dari Tabel 4 dapat disimpulkan bahwa produktivitas petani program sapta usaha tani lebih tinggi yakni sebesar $45.54 \mathrm{~kg}$ sedangkan petani non program sapta usaha tani sebesar 29,19 kg. Untuk lebih jelas dapat dilihat pada poinpoin berikut.

1. Petani program sapta usaha tani memiliki nilai tukar petani lebih tinggi yakni sebesar Rp. 224.039,87 per HOK.

2. Petani non program sapta usaha tani memiliki nilai tukar petani dibawah petani program sapta usaha tani yakni sebesar Rp.131.349,34

3. Berdasarkan kedua pernyataan diatas dapat disimpulkan perbandingan antara petani program sapta usaha tani dan non program sapta usaha tani adalah sebesar 1 berbanding 1,71. Hal tersebut menggambarkan bahwa untuk mendapatkan nilai tukar petani yang sama antara petani program sapta usaha tani dan non program sapta usaha tani maka petani non program sapta usaha tani harus bekerja selama 1,71 HOK.

Hal tersebut juga disebabkan oleh beberapa aspek seperti : Petani non program sapta usaha tani masih melaksanakan mekanisasi pertanian secara parsial, rata - rata petani masih banyak yang berpendidikan rendah yakni dibawah tamat SMP sehingga daya adopsi inovasi masih rendah, Pendapatan petani non program sapta usaha tani relatif rendah sehingga motivasi kerja rendah.

\subsubsection{Produktivitas Lahan}

Salah satu dari masalah yang dihadapi oleh sektor pertanian pangan adalah produktivitas lahan yang masih rendah. Hal tersebut akan memberikan dampak negatif pada petani tanaman pangan untuk melanjutkan usaha tani tanaman pangan. Untuk melihat keadaan produktivitas lahan pertanian pangan di Kelurahan Kempas Jaya yang terdiri dari lahan petani program sapta usaha tani dan non sapta usaha tani, dapat dilihat pada Tabel 5.

Dari Tabel 5 dapat disimpulkan bahwa produktivitas lahan petani program sapta usaha tani lebih tinggi yakni sekitar $5978,5 \mathrm{~kg}$ per hektar. Sedangkan untuk lahan petani non program sapta usaha tani sebesar $2122,61 \mathrm{~kg}$ per hektar, untuk lebih jelas dapat dilihat pada poin- poin berikut : 
1. Produktivitas lahan sapta usaha tani sudah mendekati standar produktivitas nasional yakni sebesar 7 ton perhektar dan hanya berselisih 1021,5 kg. Hal tersebut mengindikasikan bahwa petani telah melakukan budidaya padi yang sesuai dengan standar prosedur nasional.

2. Produktivitas lahan non sapta usaha tani berada jauh dibawah standar produktivitas nasional yakni sebesar 7 ton perhektar dan berselisih hingga 4877,39kg dan selisih produktivitas lahan antara kedua lahan tersebut adalah sebesar $3.855,89 \mathrm{~kg}$. Hal tersebut mengindikasikan bahwa petani masih belum melakukan budidaya padi yang sesuai dengan standar prosedur nasional.

3. Berdasarkan kedua poin diatas dapat disimpulkan bahwa perbandingan produktivitas lahan antara petani program sapta usaha tani dan non program sapta usaha tani sebesar 1 berbanding 2,82. Dimana untuk mencapai produksi yang sama maka luas lahan petani non program sapta usaha tani harus melakukan ekstensifikasi sebesar 2,82 kali.

Tabel 5. Rekapitulasi produktivitas lahan dalam usaha tani padi di Kelurahan Kempas Jaya (kg/ha_)

\begin{tabular}{|r|l|r|r|}
\hline No & \multicolumn{1}{|c|}{ Keterangan } & Sapta Usaha Tani & Non Sapta Usaha Tani \\
\hline 1 & Total Produksi & $5.978,05$ & $2.122,61$ \\
\hline 2 & Produktivitas Lahan & $5.978,5$ & $2.122,61$ \\
\hline
\end{tabular}

Sumber: Data Primer Diolah, 2016

\subsubsection{Return Cost Ratio (RCR)}

Sapta Usaha Tani merupakan program adopsi inovasi yang dilakukan oleh pemerintah terhadap petani melalui penyuluhan pertanian. Penerapan teknologi tersebut diharapkan dapat meningkatkan efektivitas dan efisiensi usahatani baik secara teknis, ekonomis dan sosial.

Menurut Sunarjono (2000), usaha tani menguntungkan atau layak diusahakan bila analisis ekonomi menunjukkan hasil layak. Adapun analisis kelayakan yang digunakan untuk menilai kelayakan usaha adalah Return Cost Ratio (RCR), atau dikenal sebagai perbandingan antara pendapatan dan biaya. Berdasarkan pernyataan tersebut maka dilakukan analisis Return Cost Ratio (RCR) dari usahatani yang dilakukan di Kelurahan Kempas Jaya yang dilihat pada Tabel 6 . Usaha tani padi yang dilakukan petani program sapta usaha tani memiliki nilai Return Cost Ratio (RCR) lebih tinggi yakni sebesar 1,37 dan petani non program sapta usaha tani sebesar 1,09. Dari kedua hasil ini diketahui bahwa usaha tani padi baik yang menerapkan program sapta maupun non sapta layak untuk diusahakan, sebab memiliki nilai RCR lebih besar dari satu. Walaupun petani yang menerapkan program sapta usaha tani memiliki nilai RCR lebih besar dari petani non sapta usaha tani. 
Tabel 6. Rekapitulasi Nilai RCR dalam usaha tani padi di Kelurahan Kempas Jaya

\begin{tabular}{|c|l|r|r|}
\hline No & \multicolumn{1}{|c|}{ Keterangan } & Sapta Usaha Tani & Non Sapta Usaha Tani \\
\hline 1 & Total Biaya (Rp) & $20.998 .082,05$ & $9.923 .238,71$ \\
\hline 2 & Total Pendapatan & $28.777 .989,25$ & $10.825 .287,36$ \\
\hline 3 & RCR & 1,37 & 1,09 \\
\hline
\end{tabular}

Sumber: Data Primer Diolah, 2016

\section{KESIMPULAN DAN SARAN}

\subsection{Kesimpulan}

Berdasarkan hasil dan pembahasan yang telah dilakukan maka dapat ditarik kesimpulan sebagai berikut :

1. Usaha tani padi yang dilakukan oleh petani program sapta usaha tani lebih baik dibandingkan dengan non program usaha tani ditinjau dari aspek pengolahan lahan, pengaturan irigasi, pemilihan benih, Pemupukan, pengendalian hama dan penyakit, pasca panen dan pemasaran.Perbandingan petani yang menerapkan sapta usahatani dengan petani non sapta usahatani dilihat dari biaya produksi pada sapta usahatani Rp.20.998.082,05 sedangkan non sapta usahatani Rp.9.923.238,71.Pendapatan

bersih sapta usahatani Rp. 7.779.907,00/ha sedangkan non sapta usahatani Rp.902.048,6/ha.Curahan tenaga kerja 131,29 HOK dan non sapta usahatani 72,72 HOK. Produktivitas luas lahan sapta usahatani $\quad 5.978,5 \quad \mathrm{~kg} / \mathrm{ha}$ sedangkan non sapta usahatani $2.122,61 \mathrm{~kg} / \mathrm{ha}$.

2. Kelayakan finansial dari kedua sistem pertanian padi tersebut dilihat dari nilai Return Cost Ratio (RCR) sudah layak. Usaha tani padi yang dilakukan petani program sapta usaha tani memiliki nilai Return Cost Ratio
(RCR) lebih tinggi yakni sebesar 1,37 dan petani non program sapta usaha tani sebesar 1,09.

\subsection{Saran}

Petani yang belum menerapkan program sapta usaha tani sebaiknya mulai mengikutinya karena hasil usahatani antara petani yang menerapkan program sapta usahatani lebih menguntungkandibandingkan dengan petani yang tidak menerapkan teknologi sapta usahatani.

\section{DAFTAR PUSTAKA}

Birowo, AT. 1974. Aspek-aspek Ekonomi Pertanian dari Masalah Perladangan. Frontir Nomor 2. Lapan Universitas Mulawarman. Samarinda.

Balai Pengkajian Teknologi Pertanian, 1992. Lima Tahun Penelitian dan Pengembangan Pertanian Gaya Teknik Offset. Bogor.

Departemen Pertanian. (2008).

Kebijakan Teknis Program

Pengembangan Usaha

Agribisnis Perdesaan:

Departemen Pertanian. Jakarta

Gunarsih. (2004). Klimatologi :

Pengaruh iklim terhadap tanahdan tanaman.Jakarta:

PT. Bumi aksara.

Mubyarto. 1989.

PengantarEkonomiPertanian. Jakarta: LP3ES 
Novizar. N. 2000. Budidaya dan Proses Diversifikasinya. Yayasan Hutanku. Padang. Sembiring. H. 2001. Komoditas Unggulan Pertanian: Badan Penelitian dan Pengembangan Teknologi. Sumatera Utara

Soekartawi. 1994. Pembangunan Pertanian.: PT. Raja Grafindo Persada. Jakarta
Sumodiningrat. 2001. Pengantar Statistika, Penerbit Andi, Jakarta

Sunarjono. 2004. Kemitraan Agribisnis. Penebar Swadaya. Jakarta 